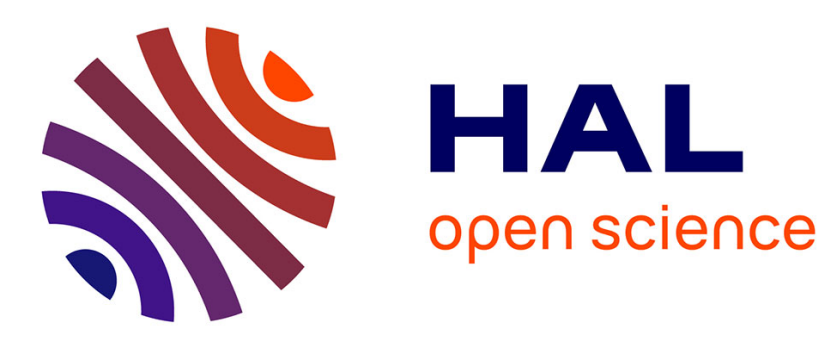

\title{
How Does the Corporate World Cope with Mega-Terrorism? Puzzling Evidence from Terrorism Insurance Markets
}

Erwann Michel-Kerjan, Burkhard Pedell

\section{- To cite this version:}

Erwann Michel-Kerjan, Burkhard Pedell. How Does the Corporate World Cope with Mega-Terrorism? Puzzling Evidence from Terrorism Insurance Markets. 2007. hal-00243051

\section{HAL Id: hal-00243051 \\ https://hal.science/hal-00243051}

Preprint submitted on 6 Feb 2008

HAL is a multi-disciplinary open access archive for the deposit and dissemination of scientific research documents, whether they are published or not. The documents may come from teaching and research institutions in France or abroad, or from public or private research centers.
L'archive ouverte pluridisciplinaire HAL, est destinée au dépôt et à la diffusion de documents scientifiques de niveau recherche, publiés ou non, émanant des établissements d'enseignement et de recherche français ou étrangers, des laboratoires publics ou privés. 


\section{ECOLE POLYTECHNIQUE}

\section{IJ}

CENTRE NATIONAL DE LA RECHERCHE SCIENTIFIQUE

How Does the Corporate World Cope with Mega-Terrorism?

Puzzling Evidence from Terrorism Insurance Markets

Erwann MICHEL-KERJAN and Burkhard PEDELL

February 2007

Cahier n 2007-05-

\section{LABORATOIRE D'ECONOMETRIE}

1rue Descartes F-75005 Paris

(33) 155558215

http://ceco.polytechnique.fr/

mailto:lyza.racon@shs.poly.polytechnique.fr 


\title{
How Does the Corporate World Cope with Mega-Terrorism? Puzzling Evidence from Terrorism Insurance Markets ${ }^{1}$
}

\author{
Erwann MICHEL-KERJAN* and Burkhard PEDELL**
}

February 2007

Cahier n 2007-05-

Résumé:

Abstract: $\quad$ Terrorist attacks that have succeeded abroad since 2001, as well as others that were prevented, indicate that the threat of a large-scale attack is real and will be with us for a long time. Focusing on the United States, the United Kingdom, and Germany, this article analyzes the role that insurance can play in providing commercial enterprises with financial protection against the economic consequences of major terrorist attacks.

The article begins by explaining the design and key features of terrorism insurance programs operating today in each of the three countries (TRIA in the U.S., Pool Re in the U.K., and Extremus in Germany). The authors then provide a detailed comparative analysis of the evolution of prices and take-up rates (based on as yet unpublished data), with particular attention to financial institutions. For those who think the U.S. is the most likely target for mega-terrorism, the findings are somewhat puzzling. On average, for example, companies in the U.S. do not pay even half as much for comparable coverage under TRIA as companies pay in Germany under Extremus.

This raises important questions. Is terrorism coverage under the U.S. insurance program now drastically underpriced? If so, what would be the likely consequences of another largescale attack in the U.S.? On the demand side, the authors observe a dramatic increase in take-up rates in the U.S. since 2003, revealing increased corporate concern. By contrast, the market penetration in Germany remains remarkably low.

The article also discusses the concept of pricing by contrasting two possible measures of price: premium over total insured value (measure commonly used today) versus premium over maximum annual compensation (real quantity of insurance purchased). Empirical evaluation of these two measures using data on these markets reveals a significant contrast.

\footnotetext{
1 Analyses provided in this article benefited from meaningful discussions over the past few years with participants in numerous conferences and roundtables on catastrophe risk management and insurance/national security related issues, including Debra Ballen, Jeffrey Brown, Frank Cilluffo, Dave Cummins, Lloyd Dixon, Neil Doherty, Martin Feldstein, Ken Froot, Scott Harrington, Claude Henry, Bruce Hoffman, Dwight Jaffee,, Paul Kleindorfer, André Laboul, Robert Litan, Jim Macdonald, Darius Lakdawalla, Patrick Lagadec, Frederic Morlaye, David Moss, Frank Nutter, Mark Pauly, Robert Reville, Irv Rosenthal, Thomas Russell, Todd Sandler, Jason Schupp, Kent Smetters, Richard Thomas, Cécile Vignial, François Vilnet, Detlof von Winterfeld and George Zanjani. We are grateful to Don Chew and Howard Kunreuther for insightful comments on earlier versions of this paper and to Steve Atkins, Chairman of Pool Re, Bruno Gas, Chairman of Extremus, Jill Johnston and John Rand from Marsh, for their willingness to share data on these markets for the purpose of this research project and insightful comments. Michel-Kerjan wishes to thank Lockheed Martin and the Wharton Risk Management and Decision Processes Center for financial support of this project. Usual disclaimer applies. A slightly different version of this working paper appeared in December 2006 in the Journal of Applied Corporate Finance, vol 18 (4).

* Center for Risk Management and Decision Processes, The Wharton School, University of Pennsylvania (Philadelphie, Etats-Unis) et Laboratoire d'économétrie, Ecole Polytechnique, Paris.

Tel (depuis la France) : 001-215-573-0515; email: ErwannMK@Wharton.upenn.edu ou erwann.michelkerjan@shs.polytechnique.fr

** University of Stuttgart (Allemagne) and Wharton Risk Center. - Email: burkhard.pedell@bwi.uni-stuttgart.de
} 
As the new Congress studies the future of terrorism risk financing after 2007, a better understanding of these programs in the U.S. and Europe and of the recent evolution of these markets will be critical. The analysis provided in this paper shall help corporate and government decision makers develop more effective protection programs against the economic consequences of mega-terrorism to ensure national security and economic growth.

Mots clés : $\quad$ Risques extrêmes - Financement - Assurance - Terrorisme de masse - Attaque nucleaire TRIA - Extremus - Pool Re - Gareat - Strategie d'entreprise et gouvernance

Key Words : $\quad$ Mega-terrorism Financing - Extreme events - Insurance and reinsurance - TRIAExtremus - Pool Re - Gareat - Corporate governance

Classification JEL: $\quad$ H56, G22, G28 
"Could we, could others, could the police have done better? Could we with greater effort, greater imagination, have stopped it?

We knew there were risks we were running. We were trying very hard and very fast to enhance our capacity, but even with the wisdom of hindsight I think it is unlikely that we would have done so, with the resources available to us at the time and the other demands placed upon us.

I think that position will remain in the foreseeable future. We will continue to stop most of them, but we will not stop all of them."

Dame Eliza Manningham-Buller, MI-5 Director-General, speaking of London Terrorist Attacks on 7 July $2005^{1}$

\section{INTRODUCTION}

Five and a half years have passed since Al Qaeda carried out the largest terrorist attack ever on U.S. soil. Does that mean this threat is over? Clearly not. Attacks that have succeeded abroad since 2001, including the London bombing on July 7,2005 , as well as other attacks that were prevented, indicate that this new type of terrorist threat will be with us for a long time.

Furthermore, this new kind of terrorism differs radically in form, motive, and scale from what other countries experienced 25 years ago. A large majority of international terrorist groups today can be classified as extremist and religious-based, with several of them seeking to inflict mass casualties and major economic disruption to the Western countries that are viewed by many of these groups as legitimate targets. In short, mega-terrorism is now a plausible scenario-one that must be taken seriously by corporate planners and risk managers.

Is your organization more or less vulnerable to such events than it was on September 11, 2001? As a corporate executive, can you be held responsible for not having protected your company's assets? More to the point, who will pay for the losses of future large-scale terrorist attacks?

This article analyzes the role that market mechanisms, specifically insurance, can play in providing commercial enterprises with financial protection against the economic consequences of major terrorist attacks. And with growing interdependencies resulting from the globalization of economic activities, large companies operating worldwide need to pay attention to how other countries in which they operate have addressed the question of terrorism loss coverage in order to determine their financial exposure here and abroad.

\footnotetext{
${ }^{1}$ Intelligence and Security Committee (2006), p. 39. The MI-5 is the British Internal National Security Agency.
} 
The evolution of terrorism insurance prices and market penetration is used here as a proxy for general corporate concern about this continuously changing threat. Building on previous work on these issues in recent years, this article focuses on three major economies: the United States, the United Kingdom and Germany. We choose the U.K. and Germany for two main reasons: First, recent events have demonstrated that both nations face the risk of attacks on their soil. Second, as in the U.S., terrorism risk coverage is not required by law for businesses in either of these countries (it is in some other OECD countries).

A better understanding of recent changes in prices and take-up rates by region and industry should help decision makers in both government and the private sector make better decisions about business strategy and national security. Indeed, such insurance purchases reflect how some commercial enterprises operating in these countries perceive the risk of being the direct victim of a terrorist attack. For example, the fact that nearly twice as many U.S. companies are buying terrorism insurance today as in 2003 can be interpreted to some extent as a reliable indication of increased concern. Moreover, $80 \%$ of financial institutions in the U.S. now have some kind of terrorism insurance-the highest take-up rate across all industries.

This article also analyzes the evolution of prices over the past three years. The problem in interpreting any price behavior related to terrorism insurance is the difficulty in deciding on a reference point. Before 9/11, terrorism was an unnamed peril in most commercial policies and so the risk was not specifically priced. Moreover, given the impossibility of establishing a rigorous probability distribution for any specific scenario of attack, how can one determine the expected losses_and thus the "right" price? Is a $\$ 50,000$ terrorism insurance premium for a firm with $\$ 500$ million of total insured value an expensive deal, or a bargain?

To the best of our knowledge, this paper is the first attempt to evaluate price and take-up rates in other countries so as to be able to make comparisons. What we have found might be somewhat puzzling for those who think the U.S. is the most likely target for terrorism. For instance, the available data suggest that the average company in the U.S. (covered by TRIA) does not even pay half of what companies pay in Germany for a roughly comparable level of coverage under its national terrorism insurance program. Is it possible that the U.S. market for terrorism insurance is now drastically underpriced? ${ }^{2}$ If so, the next mega-attack on U.S. soil is likely to be another wake-up call for insurers, as 9/11 was eight years after the first World Trade Center attack in 1993.

The study is organized as follows. The next section of this paper discusses some of the key challenges associated with the new era of large-scale catastrophes, and how mega-terrorism differs from other extreme events such as natural disasters. Its features make this risk a special category unto itself, one that is much more challenging than other catastrophic risks. We also discuss recent evidence on the evolution of this threat. The following section analyzes the insurance market's reaction

\footnotetext{
${ }^{2}$ As we discuss below, prices for stand-alone terrorism insurance can be much higher than for TRIA coverage.
} 
to the 9/11 attacks. After that, we discuss the key elements of terrorism insurance programs currently in place in the U.K., Germany, and the U.S. We then focus on the recent evolution of prices and market penetration by both location and industry sectors, with particular focus on financial institutions. This empirical analysis benefits from as-yet-unpublished data on the U.S. and German markets; to our knowledge, no extensive datasets on prices and take-up rates have been collected on the British market.

\section{A New Era of Large-scale Catastrophes: Dealing with Mega-Terrorism Risk}

Some continue to argue that catastrophes have always been with us, and that there is no need to be more worried about such events than before. Catastrophes are certainly not new, but the nature and scale of catastrophic risks have changed dramatically in the past few years. In addition to the 9/11 attacks five years ago, we have witnessed the 2003 U.S.- Canada blackout, the Indian Ocean Tsunami, and the series of hurricanes that devastated Florida in 2004 and other parts of the U.S. coast in 2005. Will 2007 or 2008 be even worse?

All these events appear to have followed one another at an accelerated pace and with an unprecedented scale of devastation. The nature of international terrorism has in fact changed drastically in the past two decades. Twenty years ago, terrorism consisted primarily of local political activities. But recent years have seen the emergence of a new kind of threat: extremist, religious-based terrorism (Hoffman, 2006-a; Enders and Sandler, 2006). Most of these terrorist groups, including Al Qaeda, have demonstrated a willingness to inflict mass casualties and to view civilians as a legitimate target. That change has led to fewer, but larger attacks with a considerably larger number of casualties.

The world's 15 worst terrorist attacks, as indicated by the number of casualties and fatalities, have all occurred since 1982, with two-thirds of them occurring between 1993 and 2006. Moreover, there have been many near misses in the last few years that would clearly have appeared in this ranking had we failed to prevent them. Among the most recent that were made public were the attempted bombings of commuter trains in Germany on July 31, 2006 and the thwarting of a plot to bomb up to ten passenger planes bound for the U.S. from the U.K. in August 2006.

Conventional wisdom holds that the major efforts undertaken in the past five years have led to the dismantlement of Al Qaeda, and of other international terrorist groups. Recently, Al Qaeda has often been depicted as a broken and beaten organization that would not be capable in any way of perpetrating new large-scale attacks on its own. The reality of it, unfortunately, seems to be somewhat different. Recent evidence suggests that Al Qaeda has not only survived but has re-grouped and re-organized, and it is now marshalling its forces. In other words, taking the absence of mega-attacks on U.S. soil in the past five years as a sign of weakness of 
Al Qaeda would be wrong, and dangerous ${ }^{3}$. While any forecast of the evolution of international terrorism in the coming years is beyond the scope of this paper, what is clear is that the U.S. and other Western countries remain at risk of large-scale attacks by extremist terrorist groups.

Moreover, the type of target has also changed over time. Traditionally, attacks were aimed at federal targets (government, military, diplomatic). While security has increased in government buildings here and abroad, terrorist groups have switched to businesses that represent values and economic interests of Western countries.

For example, in recent years, the majority of U.S. targets attacked throughout the world have been businesses (it was over $80 \%$ in 2000 and nearly $90 \%$ in 2001) (U.S. Department of State, 2004). ${ }^{4}$ And it seems clear that private-sector entities will remain a major target of these terrorist organizations. Global companies usually operate in, ship to, or supply from many countries, some of them facing very unstable environments (including, in some cases, repeated terrorist attacks or even civil war). In this paper, then, we focus on mega-attacks, which in the field of risk management fit into a special category called "extreme" events. One must begin by recognizing that managing and arranging post-loss financing for such low-probability, large-loss events does not mean more of the same kind of responses to smaller and local accidents. One must have a different approach to be prepared for these possibilities.

Large terrorist attacks have the potential to destabilize entire nations, with numerous ripple effects and long-term impacts. In other words, major interests are at stake. Crisis management of such events is different, too, because it requires immediate coordination of a very large number of decision-makers who often have never worked together before and have very different agendas. ${ }^{5}$ Disasters also force decision-makers to confront the pressure exerted by the media's 24/7 live coverage. The task of securing financial protection against extreme events is also of a different order of magnitude, since catastrophic losses are typically both immediate and highly correlated-and the losses resulting from business interruption can also be very large.

While mega-terrorism risk shares most of the features of low-probability, extreme risks, it also presents a set of distinctive characteristics that can seriously challenge companies' capacity to deal with this emerging threat. We discuss 7 of them below:

- First, there are many plausible scenarios of attacks that would lead to overwhelming losses; the possible methods of a mega-terrorist attack are limited only by terrorists' ingenuity. Consider the following illustration. The direct property losses, business interruption costs, and workers' compensation payments resulting from a five-ton truck bomb in one of the tallest high-rises in a major U.S. city could go as high as $\$ 15$ billion

\footnotetext{
${ }^{3}$ We thank Bruce Hoffman (formerly at Rand, now at Georgetown University) for sharing his view with us on the current operation of Al Qaeda. See B. Hoffman (2006-b).

${ }^{4}$ Data do not cover the conflict in Iraq.

${ }^{5}$ For challenges associated with leadership during such crisis episodes, see Lagadec and MichelKerjan (2005).
} 
for a single building, depending on the location and the timing of the attack. Simultaneous attacks could inflict losses in the $\$ 100$ billion range. ${ }^{6}$ The use of socalled weapons of mass destruction (WMD) is even more threatening. A 10-kiloton nuclear bomb planted in a shipping container that explodes in the Port of Long Beach, California could have an even more devastating impact, with total direct costs estimated to exceed $\$ 1$ trillion (not to mention ripple effects on trade and global supply chains; the ports of LA and Long Beach handle $30 \%$ of U.S. shipping imports by value and are the largest port of entry in the U.S.) (Meade and Molander, 2006 ${ }^{7}$ )

- Second, there are substantial interdependencies and the origin of the attack and its effects do not require proximity; for example, the destruction of the World Trade Center's towers in New York City could be attributed in part to the failure of security at Logan Airport in Boston, which shows that one company's operation can be disrupted by the failure of others to take sufficient protection measures (Kunreuther and Michelkerjan, 2005-b);

- Third, and related to interdependencies, actions to protect one potential target can increase the likelihood that other targets will be attacked ${ }^{8}$, some types of "security externalities" which are critical to consider;

- Fourth, in contrast to natural disasters, for which large historical databases and scientific studies are publicly available, data on current terrorism threats are either not available at all or partly concealed by federal agencies for national security reasons;

- Fifth in addition to the lack of historical data relevant to the nature of today's threat, estimating the likelihood of a terrorist attack means aiming at a moving target, resulting in dynamic uncertainty, which is a key feature of terrorism risk. As a result, firms face a serious problem in quantifying terrorism risk and evaluating the best strategy to protect their assets;

- Sixth, is uncertainty about the timing of an attack. From the eight years that separated the first World Trade Center bombing in 1993 and the 2001 attacks, one could infer that terrorist groups program their attacks far in advance and strike when the public's attention and concern about terrorism have receded;

- Finally, and of great importance, when it comes to sharing the watch and responsibilities, a government's actions here and abroad directly affect the level of risk imposed on businesses and citizens (security measures, intelligence, foreign policy). All of these characteristics have influenced the insurance programs established by different countries to provide financial protection against terrorism. ${ }^{9}$

\footnotetext{
${ }^{6}$ See Chapter 6 in Wharton Risk Center (2005).

${ }^{7}$ Rosoff and von Winterfeldt (2005) also analyzes the human and economic impacts of a dirty bomb exploding in these ports for different scenarios of attacks.

${ }^{8}$ For that reason, insurance can constitute a better risk management tool at a global level than local investment in security measures; see Lakdawalla and Zanjani (2005).

9 On insurability of mega-terrorism, see Kunreuther and Michel-Kerjan (2005-a) and Government Accountability Office (GAO) (2006). We also recognize that insurance is only one tool to protect a
} 


\section{The MARKet's ReACtion to 9/11: The CASE OF TeRrorism INSURANCE ${ }^{10}$}

Before September 2001-and despite terrorist attacks that occurred in the 1990s in several European countries, including Spain, France and the U.K., and the first attack on the World Trade Center in New York City in 1993-terrorism was effectively covered as an unnamed peril by standard all risk commercial policies in the U.S. Hence, on the morning of $9 / 11$, many companies that suffered the attacks may have been surprised to discover that they were actually covered against such events. And many insurers and their reinsurers were brought to the realization that they were financially responsible for the insured portion of the losses: \$35 billion, one-third of which was for business interruption.

At that time, this was the most costly catastrophe ever in the history of insurance (now the second after Hurricane Katrina). Reinsurers, most of them European companies, were responsible for about two-thirds of these losses. Thus, from an insurance perspective-an aspect that has certainly been overshadowed by the human tragedy-9/11 has been primarily a European crisis. What's more, these reinsurance payments came in the wake of portfolio losses due to recent stock market declines and of outlays triggered by a series of catastrophic natural disasters over the past decade. Having their capital bases severely hit, most reinsurers decided to reduce their terrorism coverage drastically or to eliminate it.

Thus, in the immediate aftermath of September 11, 2001, insurers in the U.S. and other countries found themselves with significant amounts of terrorism exposure from their existing portfolio, with limited possibilities of obtaining reinsurance to reduce the losses from a future attack. ${ }^{11}$ The few insurers that continued to provide coverage to their clients charged very high prices. In the U.S. in October 2001, the Insurance Services Office, on behalf of subscribing insurance companies, filed requests in every state for approval of policy forms that would permit insurers to exclude terrorism from most commercial insurance coverage (with the exception of workers' compensation). And by early 2002, 45 states permitted insurance companies to use these exclusions, except for two types of coverage: workers' compensation (occupational injuries are typically covered without regard to the peril that caused the injury) and fire policies in states (nearly half of the U.S.) with laws stipulating that losses from fire are covered regardless of cause.

Commercial enterprises thus found themselves in a very difficult situation, with insurance capacity extremely limited and prices very high. Consider the case of insuring Chicago's O'Hare Airport. Prior to 9/11 the airport had $\$ 750$ million of

company against financial consequences of a terrorist attack; for instance, a public firm might prefer going partially uncovered and spread the losses it would suffer from an attack against all its shareholders.

${ }^{10}$ This section is based on Kunreuther and Michel-Kerjan (2004).

${ }^{11}$ Several studies have estimated the impact of 9/11 on the insurance market in particular and on the economy in general; see Doherty, Lamm-Tennant and Starks (2003), Cummins and Lewis (2003), and Chapter 7 in Wharton Risk Center (2005). 
terrorism insurance coverage at an annual premium of $\$ 125,000$. After the terrorist attacks, insurers offered the airport only $\$ 150$ million of coverage at an annual premium of $\$ 6.9$ million (representing an increase in the premium over coverage ratio of over 275!). The airport was forced to purchase this policy since it could not operate without coverage (Jaffee and Russell, 2003). Another example is the Golden Gate Park in San Francisco, which was unable to obtain terrorism coverage; moreover, even its non-terrorism coverage was reduced from \$125 million to \$25 million-and the premiums for this reduced amount of protection increased from $\$ 500,000$ in 2001 to $\$ 1.1$ million in 2002 (Smetters, 2004).

The result of such changes, as remarkable as it now seems, is that one year after 9/11, when national security had became the priority number one on the U.S. national and international agendas, the country's commercial enterprises remained largely uncovered at home (Hale, 2002). If another large-scale attack had occurred at that time, the impact on the economy would have been much more serious. This time the economic losses would not have been spread over a large number of insurers and reinsurers worldwide but, in the absence of massive government funding, sustained by the firms themselves.

After the 2002 mid-term elections, and under pressure exerted by several interest groups, the Terrorism Risk Insurance Act of 2002 (TRIA) was eventually passed by Congress on November 26, 2002, and signed into law by the President the month after (U.S. Congress, 2002). TRIA required insurers to offer terrorism coverage to commercial enterprises and provided insurers with a federal backstop for insured losses of up to $\$ 100$ billion. At the end of 2005 , the program was renewed until December 2007 by the Terrorism Risk Insurance Extension Act of 2005 (TRIEA; U.S. Congress, 2005) (NB: In the rest of the paper we use TRIA and TRIEA interchangeably, except when the distinction is needed.)

During the same period, companies operating in Germany saw the creation of a special insurance company, called "Extremus," that covers terrorism exclusively, and benefits from federal back-up as well. Extremus was officially launched in September $2002 .{ }^{12}$ We now briefly describe the U.S. program and compare it to both Extremus and Pool Re, the U.K. terrorism re-insurance program that was established in 1993 and modified after $9 / 11$.

\section{Programs in the U.S., the U.K. And Germany}

\section{TRIA, the U.S. Terrorism (Re-)Insurance Program}

Under TRIA, insurers are obliged to offer terrorism coverage to all their insureds (a legal "make available" requirement) and the coverage limits and deductibles must be the same as for any loss from other major perils on their commercial policy. Clients have the right to refuse this coverage unless it is mandated

\footnotetext{
${ }^{12}$ Several other countries established or modified their government-back-stop insurance programs as a result to the 9/11 attacks; see OECD (2005) and U.S. Government Accountability Office (GAO) (2005).
} 
by state law, as in the case of workers' compensation lines in most states. ${ }^{13}$ Insured losses are covered under TRIA only if the event is certified by the Treasury Secretary as a foreign act of terrorism and only for total losses higher than $\$ 50$ million (in 2006) and $\$ 100$ million (in 2007). Therefore, an event like the Oklahoma City bombing of 1995 would not be covered because it would be considered domestic terrorism.

We believe that this distinction between international and domestic terrorism is an important source of uncertainty about the coverage companies are really buying when they purchase a TRIA-type policy. Indeed, the tendency of locally organized and even national groups to become part of international terrorist networks often makes it difficult to distinguish between domestic and foreign terrorism, as illustrated by the July 2005 bombings in London. Because some of these terrorists had been trained in Pakistan, can one thus conclude that they were "acting on behalf of a foreign person or foreign interest?" On the other hand, they had been studying or working in London for years. In that case, should we conclude that the nearly 800 casualties were victims of domestic terrorism?

Had these events occurred in the U.S. and been more financially damaging, would they have qualified for TRIA coverage? Today this gray zone is likely to inflict legal costs on both victims and insurers, while causing major delays in claims payments to victims of the attacks. Another major limitation of TRIA in protecting assets against mega-terrorism is its stipulation that losses resulting from chemical, biological, radiological, and nuclear terrorist attacks (CBRN) are covered by TRIA only if such perils are specifically covered in the original property and business interruption insurance policy, which is usually not the case (or, if it is, for a very limited capacity); but they are covered for workers' compensation. ${ }^{14}$

\section{Pay as You Go and-Don't-Go}

Under TRIA, there is a specific risk-sharing arrangement between all commercial firms (whether covered for terrorism or not), insurers, and the federal government that operates with two layers. The first layer is provided by insurers through a "deductible" that is calculated as a percentage of the direct commercial property and casualty earned premiums of each insurer in the preceding year. The percentage increases sharply over time: $7 \%$ in $2003,10 \%$ in $2004,15 \%$ in 2005 , $17.5 \%$ in 2006 and $20 \%$ in 2007.

As illustrative figures, a Morgan Stanley study estimates that AIG's 2004 deductible would have been $\$ 2.7$ billion. Other insurers, such as Travelers, ACE, Chubb and Berkshire had lower 2004 deductibles: \$928 million, \$743 million, \$600 million and \$200 million, respectively (Morgan Stanley, 2004). According to analysis we undertook as part of the 2005 Wharton Risk Center study cited earlier, projections

\footnotetext{
${ }^{13}$ Workers' compensation coverage is mandatory for a large majority of employers in all states other than Texas where it is optional. Employers must either purchase insurance or qualify to self-insure. Workers' compensation laws do not permit employers or insurers to exclude coverage for worker injuries caused by terrorism.

${ }^{14}$ TRIEA excludes some additional risks such as automobile, burglary, surety, and professional liability.
} 
indicated that deductibles would have nearly doubled in real terms, or even tripled, by 2007.

The second layer up to $\$ 100$ billion is the joint responsibility of the federal government and insurers. Specifically, under TRIEA 2007 the federal government is responsible for paying $85 \%$ (90\% in 2006) of each insurer's primary property-casualty losses during a given year above the applicable insurer deductible; the insurer covers the remaining $15 \%$ (19\% in 2006). The federal government does not receive any premium for providing this reinsurance coverage. Hence, the final price paid by a commercial firm for insurance coverage under TRIA today is much lower than it would be without the free up-front reinsurance provided by the government program (see the discussion on pricing issues below).

There is also a specific feature in the operation of TRIA that has gone relatively unnoticed in the corporate world: the ex post "mandatory recoupment" by the federal government. In the event the insurance industry suffers insured terrorism losses that require the government to cover part of the claims, these outlays must be partly recouped ex post through a mandatory policy surcharge against the insurers.

The insurers are then expected to pass that surcharge on to all property and casualty insurance policyholders, whether or not the insured has purchased terrorism coverage, with a maximum of $3 \%$ of the premium charged under the policy that year. This recoupment applies only for federal reimbursements that consist of the total payments by the insurance industry (threshold) plus an amount designated as the "industry retention." The scheduled amounts for industry retention increases over time as follows: $\$ 10$ billion in 2003 , $\$ 12.5$ billion in 2004 , $\$ 15$ billion in 2005 , $\$ 25$ billion in 2006 , and $\$ 27.5$ billion in 2007 . For insured losses above the industry retention, it is unclear how loss will be eventually spread. Indeed, the current law allows the government considerable discretion in this, and thus its response will likely be subject to political influence.

The upshot, then, is that a company that has decided not to buy terrorism insurance could effectively end up paying for the losses of other companies that are at least partly covered. In other words, it's pay as you don't go.

As illustrated by the following example, depending on the size of the attack and the insurance penetration, this recoupment portion could be quite large. Using data provided by the rating agency AM Best on the top 450 insurers for property lines and workers' compensation lines in the U.S., it has been shown that an attack perpetrated in New York City that would inflict $\$ 40$ billion of direct losses, including $\$ 34$ billion of insured losses (\$28 billion for workers' compensation, which is $100 \%$ covered, and $\$ 6$ billion for property, assuming a $50 \%$ take-up rate), would lead to a payment of $\$ 18.7$ billion by the insurers, $\$ 9$ billion by the federal government, and $\$ 6.3$ billion by all commercial policyholders (in the form of an ex post surcharge) (Kunreuther and Michel-Kerjan, 2006). ${ }^{15}$

\footnotetext{
${ }^{15}$ In Kunreuther and Michel-Kerjan (2006) we provide an extensive series of analyses of terrorism losssharing under TRIA based on a large number of scenarios of attacks in large cities, insurance penetration and market share.
} 


\section{Pool Re-The U.K. Program}

Crossing the Atlantic Ocean, we find that the current financial mechanism for covering companies against the economic consequences of a terrorist attack is somewhat different in the U.K. For one thing, companies operating there have had a longer history of dealing with terrorist threats (especially those posed by the Irish Republican Army (IRA)), albeit of a much smaller magnitude than the 9/11 attacks. In the wake of the terrorist bomb explosions in London in April 1992, which cost insurers nearly $\$ 700$ million, and an announcement seven months later by British insurers that they would exclude terrorism coverage from their commercial policies, the U.K. established a mutual reinsurance organization (Pool Re) in 1993 for commercial property and business interruption to accommodate claims resulting from acts of terrorism. The program does not cover any other classes.

Until September 11, 2001, terrorism exclusions in U.K. insurance policies were usually limited to fire and explosion. They were based on the definition of an act of terrorism contained in the Reinsurance (Acts of Terrorism) Act 1993. The scale of 9/11 attacks in the U.S. led to a major revamping of Pool Re.

Since the end of 2002, protection of companies operating in the U.K. under Pool Re has been extended to "all risks," a category that now includes damage caused by chemical and biological as well as nuclear contamination (while war and related perils as well as computer hacking continue to be excluded). The inclusion of such risks constitutes an important difference from the U.S. and German terrorism insurance programs, which typically do not provide coverage for losses due to CBRN.

Pool $\mathrm{Re}$ acts as a reinsurer for all insurers that wish to be a member of the pool; the U.K. Treasury in turn provides Pool Re with unlimited coverage (unlimited debt issuance to be accurate; the pool will have to reimburse the U.K. government over time). Pool Re's right to draw funds under the retrocession agreement with the government is determined on a strict "cash needs" basis. That means that premium income earned by Pool Re during the time necessary for claims settlement, i.e. after a terrorist attack, will also be used to pay these claims, if necessary.

Pool Re shares $10 \%$ of its collected premiums with the U.K. government to benefit from this cover. As of December 2005, Pool Re had 273 members (91 insurers incorporated in the U.K., 39 Lloyd's syndicates, and 143 insurers incorporated elsewhere). Their individual retention before being reimbursed by the pool is based on their proportion of participation in Pool Re that is applied to the upfront industry retention ( $£ 100$ million per event, $£ 200$ million per year in 2006).

To illustrate this arrangement, consider an insurer with a 1\% terrorism market share that suffers a $£ 1$ billion loss from a large terrorist attack in the U.K. The insurer's individual retention amounts to $£ 1$ million ( $1 \%$ of the $£ 100$ million industry retention per event), and it would recover from Pool Re the entire amount of the loss in excess of that amount, i.e. $£ 999$ million.

Roughly estimated, the current reserves of Pool Re are $£ 2.5$ billion. The U.K. Treasury backs Pool Re only if these reserves and its members' payments (the individual retentions of insurers affected) are insufficient to compensate the insured 
losses. Hence, the actual market retention is determined by which insurer members are involved and to what extent.

Take, for example, a terrorist attack that inflicts $£ 10$ billion in insured losses today. The private insurers that are members of Pool Re and involved in the loss would pay their individual retentions. Assuming for the sake of simplicity that all members are involved in the loss, they would share the first $£ 100$ million (only one event). Pool Re would exhaust its current reserves of $£ 2.5$ billion plus the income that would be earned until claims are settled - and that could be substantial. Assuming it would take three or four years for Pool Re to pay all its claims, and there is no other attack on the U.K. in the meantime, its income in the interim could amount to $£ 1.5$ billion. ${ }^{16}$ Under such a scenario, the British government would pay the remaining $£ 5.9$ billion. It's also important to keep in mind that the government will get reimbursed for that by the pool over time; and at the end of the day, the members of Pool Re will have paid all insured losses due to this terrorist attack.

\section{Extremus-The German Program}

As in other countries, until the events of $9 / 11$, coverage against terrorism risk was included in all commercial lines in Germany without an explicit extra premium. After 9/11, the extremely limited availability of terrorism coverage led to the founding of Extremus AG, a federal government-backed property insurance corporation that started operations on November 1, 2002. Unlike Pool Re, Extremus is not a reinsurance institution but a private insurance company. Its annual capacity to pay for claims is $€ 10$ billion. It is completely reinsured by national and international insurance and reinsurance companies (first layer limited to a total of $€ 2$ billion), as well as by the federal government (second layer of €8 billion). In return, the federal government participates in the premium income. ${ }^{17}$

Extremus provides coverage against terrorist acts for buildings, contents of buildings such as machinery, and business interruption. But only risks with total insured value over €25 million are eligible for coverage. As in the U.S. and the U.K., companies operating in Germany are not required to purchase insurance against terrorism (they are required to do so in other OECD countries). If they want such coverage, it can only be obtained as a sidecar of existing property and/or business interruption insurance. In that case, the additional terrorism coverage applies to the total insured value of the existing contracts for property and business interruption respectively. When buying terrorism coverage from Extremus, companies need thus to specify a maximum annual compensation that is equal to or smaller than the total value insured. In any event, however, the annual compensation for any company is capped at a maximum of $€ 1.5$ billion.

\footnotetext{
${ }^{16}$ The current annual premiums collected by Pool Re are nearly $£ 300$ million; a major attack in the U.K. would certainly contribute to increase this figure in the $£ 400-500$ million range (personal communication with Pool Re).

${ }^{17}$ As is the case with Pool Re but not with TRIA, the reinsurance provided to Extremus by the federal government is not free of charge: the government receives approximately $12.5 \%$ of the premiums collected by Extremus.
} 
This means that a company with a total insured value greater than $€ 1.5$ billion can get only partial coverage for terrorism risk. For instance, we know of a company with a total insured value of $€ 25$ billion for which the $€ 1.5$ billion cap on limit means that it can purchase coverage for only $6 \%$ of its total insured value from Extremus.

A number of risks are explicitly excluded from Extremus coverage, such as nuclear risks as well as biological and chemical contamination by terrorists, war and civil war, insurrection, and looting. Furthermore, losses due to computer viruses are also not covered. In principle, eligibility requires that the act of terrorism be committed in Germany and that the loss occur in Germany as well. ${ }^{18}$

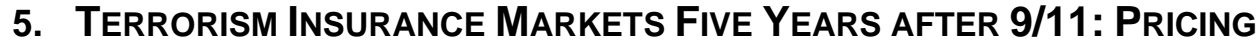 (THE COST OF TERRORISM INSURANCE BY COUNTRY, LOCATION, AND INDUSTRY)}

Having discussed the main characteristics of the terrorism risk insurance programs in the U.S., the U.K., and Germany, we now focus on two metrics-the price of terrorism insurance in these countries and the extent of market penetration-and on two questions: How have these metrics evolved over time? And what have been the main drivers of such change?

We must start by noting that there is nothing like a national or international body that systematically collects data about price of coverage and insurance penetration. The data provided here thus must be viewed with some caution. But whatever their limitations, they do provide some insight into the recent evolution of these markets and a basis for cross-country comparison.

\section{U.K. (pricing rule for Pool Re)}

Pool Re, which presents the simplest pricing rule of the three cases we analyze in these pages, charges its members a separate, optional premium for terrorism reinsurance coverage, one that can be calculated as a percentage of the total value of the property exposed under a fire and accident policy for material damage ${ }^{19}$

This material damage rate depends only on geographical zones by postcode within the United Kingdom: $0.03 \%$ of the value of the property exposed for material damage in Central London and other major cities; $0.006 \%$ elsewhere in the U.K., excluding northern islands and territorial waters which are not covered by the program. There is also additional reinsurance coverage for business interruption that carries a uniform charge of $0.021 \%$ of the value of the property exposed throughout the U.K. (which can differ from the one exposed for material damage). A decision by

\footnotetext{
${ }^{18}$ In the year 2006, Extremus offered its insureds for the first time the possibility of arranging coverage for assets in other EU countries, assuming the role of a broker. The risks are born by a consortium of Lloyd's syndicates and by Inter Hannover in London that also set premium rates, but contracts are based on the terms and conditions of Extremus and subject to German law. As of April 2006, ten contracts with an aggregate insured value of $€ 1$ billion existed under this line. For obvious reasons, the German government does not provide reinsurance for this line.

19 This is an important difference from the reinsurance provided to insurers by TRIA for free (at least upfront; see above discussion on ex post recoupment).
} 
the policyholder to adopt a coverage limit lower than the total value of the property exposed would not affect Pool Re's pricing rule.

These premiums reflect a $100 \%$ increase that became effective in 2003 and that can be attributed to the extension in coverage to all risks by the pool.

Moreover, until the changes were enacted in 2003, insurers would have charged their insureds the price charged by Pool Re for reinsuring their risks, plus a management fee. Since 2003, however, insurers are now free to set the premiums for underlying terrorism policies, thus introducing competition into the terrorism insurance market. To ensure a "level playing field," Pool Re sets its rates so that the reinsurance cost for a property introduced to the scheme is the same for all members-that is, the members are all charged under an identical rating structure. It is this rating structure between Pool Re and its members that has the four geographical zones introduced above, and it is important to distinguish this from the arrangement between Pool Re's members and their insureds whereby the member is free to determine whatever rating basis they may charge.

To our knowledge, no systematic data collection of terrorism insurance prices charged by primary insurers in the U.K. has been undertaken thus far. So beyond a handful of anecdotes that are circulating, it is not clear at this point what changes in pricing by primary insurers (relative to Pool Re charges) have resulted from such an open market. For that reason, we concentrate mostly on the U.S. and German markets in the rest of the paper.

\section{Germany (pricing rule for small-medium accounts)}

Premiums for terrorism coverage by the German Extremus vary with respect to two elements: (1) the total insured value (TIV) of the company for property lines; and (2) the insured's choice of a maximum annual compensation (limit) the company will receive if it suffers terrorist attacks.

By specifying a limit lower than TIV, a firm in Germany can bring down its cost for terrorism coverage (Extremus Versicherungs-AG, 2005). Premiums for companies with TIV higher than $€ 150$ million are set through individual negotiations and are not published. The only premium rate information available from Extremus is the maximum premium rate as a percentage of TIV for the $€ 150$ million- $€ 500$ million segment that has been set at $0.048 \%$ since 2005 .

This maximum rate clearly applies to contracts with limits equal to TIV; however, it is not publicly known for which part of the entire segment it is relevant. This maximum rate had been cut down from nearly $0.1 \%$ in 2003 and $0.06 \%$ in 2004 . 
Table 1: Premium example for the German Extremus (2006)

\begin{tabular}{lllll}
\hline TIV (a) & Limit (b) & $\begin{array}{l}\text { Annual premium for terrorism } \\
\text { coverage }\end{array}$ & & \\
\cline { 3 - 5 } & & in $€$ & in \% of $(\mathrm{a})$ & in \% of $(\mathrm{b})$ \\
\hline 150 million & 50 million & 28,333 & 0.019 & 0.057 \\
150 million & 100 million & 39,166 & 0.026 & 0.039 \\
150 million & 150 million & 50,000 & 0.033 & 0.033 \\
\hline
\end{tabular}

According to Extremus, these were the only tariff changes made since the start of operation in 2002. For companies with TIV between $€ 25$ million (a firm is not eligible for Extremus below that threshold) and $€ 150$ million (about $85 \%$ of the existing contracts), premiums can be calculated according to a pre-defined pricing rule with the help of a tool made available by Extremus. ${ }^{20}$

Table 1 exhibits some premium examples for a TIV of $€ 150$ million and shows how an insured can bring down its premium by specifying a limit lower than TIV. The annual premium for terrorism coverage for a TIV of $€ 150$ million with an annual limit of $€ 150$ million amounts to $€ 50,000$. By choosing a lower annual limit of $€ 100$ million, the same firm could reduce its premium to $€ 39,166$; and by choosing a still lower annual limit of $€ 50$ million, it could drop the premium to $€ 28,333 .{ }^{21}$

While the premium paid per euro of TIV of this firm decreases by lowering its coverage limit, the premium paid per euro of quantity of coverage increases; the latter effect is partly due to the fact that a higher ratio of insured assets over limit can be viewed as increasing the likelihood that the compensation will be claimed.

The decision by a company to choose a limit lower than the total value of its insured assets depends on how it perceives the risk of losing some, or all, of its assets in case of a terrorist attack. If a firm expects to lose only a small part of its assets because, say, its operations are regionally diversified in many locations, it is likely to choose a relatively low limit for the sake of a lower insurance premium (e.g., one that covers, for example, just the value of its most costly property).

The pricing rule of terrorism insurance by Extremus for this €25 million-€150 million segment means that, in contrast to the U.S. and the U.K., there is no premium

\footnotetext{
${ }^{20}$ Extremus no longer publishes premiums for risks with total value insured of above $€ 150$ million. This limits the analysis of the pricing scheme of Extremus, all the more as the distribution of premium income is heavily biased towards the largest insurance contracts. The 10 largest contracts for instance, all of them with maximum annual compensation between $€ 500$ million and $€ 1.5$ billion, account for $62 \%$ of total value insured by Extremus, for $10 \%$ of maximum annual compensation and for half of the total net premium income.

${ }^{21}$ Further premium examples can be found in a companion paper, Michel-Kerjan and Pedell (2005).
} 
discrimination in Germany with respect to industry and geographical location. For that reason, coverage by Extremus might be seen as less attractive for companies with properties located in the countryside or doing business in industry sectors considered less exposed. This lack of premium discrimination, based on location and industry sector, is likely to be one of the main obstacles to an increase in the demand for terrorism risk coverage (see below).

By the end of September 2006, the portfolio of Extremus consisted of 1,153 contracts signed by firms for which the cumulative TIV was $€ 409$ billion in insured value. The sum of total limits for all these contracts was €92 billion, yielding an aggregate net premium income charged by Extremus of $€ 63$ million. For sake of comparison with prices in the U.K. the U.S. (see below), these figures indicate an average "premium over total insured value" of $0.0154 \%$ and an average "premium over limit" of $0.0685 \%$.

\section{The U.S. (no pricing rule)}

Unlike Pool Re (reinsurance) and Extremus (insurance), TRIA does not define any national pricing rule. Moreover, the Treasury that operates TRIA does not collect systematically data on prices and take-up rates for terrorism insurance market in the U.S. Fortunately, surveys undertaken on a regular basis since the inception of TRIA by Marsh and Aon, the two largest insurance brokers operating in the U.S., provide a good representation of the market for medium and large accounts.

According to a recent Marsh survey of over 1,600 client firms in the U.S. that covers the past 11 quarters, the cost of property terrorism insurance decreased significantly in 2005. The median terrorism rate, which is calculated as the ratio of premium to total insured value (and is the figure used by most of the surveys of the U.S. market), fell from $0.0057 \%$ in 2004 to $0.0042 \%$ in 2005 , indicating a decline of the average cost of terrorism coverage of over $25 \%{ }^{22}$ In other words, a firm representing the median Marsh client with $\$ 100$ million assets would have paid $\$ 5,700$ for terrorism coverage in 2004 and only $\$ 4,200$ in 2005. (Marsh, 2006).

This trend continued in 2006. Referring to a fixed sample of 189 Marsh accounts, the President's Working Group on Financial Markets reports that the median rates against total insured value decreased from $0.0044 \%$ in 2005 to $0.0038 \%$ as of July 2006 (President's Working Group on Financial Markets, 2006).

And although these premiums still remain higher for major metropolitan areas, median terrorism insurance prices in different regions appear to be converging. ${ }^{23}$ But a closer look by industry reveals important disparity.

\footnotetext{
${ }^{22}$ These figures include TRIA policies, non-certified policies, stand-alone policies and placements made through captives. Price is typically much lower for TRIA-only coverage than for TRIA and non-certified events combined, or for stand-alone which tends to be the most expensive (see discussion below); but even for stand-alone terrorism coverage rates have also declined (40-50\% from 2002 to the first quarter of 2006; see Aon, 2006-a).

${ }^{23}$ For example, in the past 18 months, the median premium as a percentage of total insured value in the Midwest (0.0038) is now quite close to the median premium in the Northeast $(0.0047)$.
} 
Figure 1 below depicts the evolution of terrorism insurance prices between 2003 and 2005 for different sectors among Marsh clients. These data-the latest that are publicly available as we write this paper-reveal considerable differences among industries. For example, the price of terrorism insurance for financial institutions is about twice as high as in the real estate and media sectors, and three times as high as in education and retail.

Figure 1. Terrorism Pricing in the US, by Sector, as a \% of TIV - 2003-2005 (Median Rates in percent)

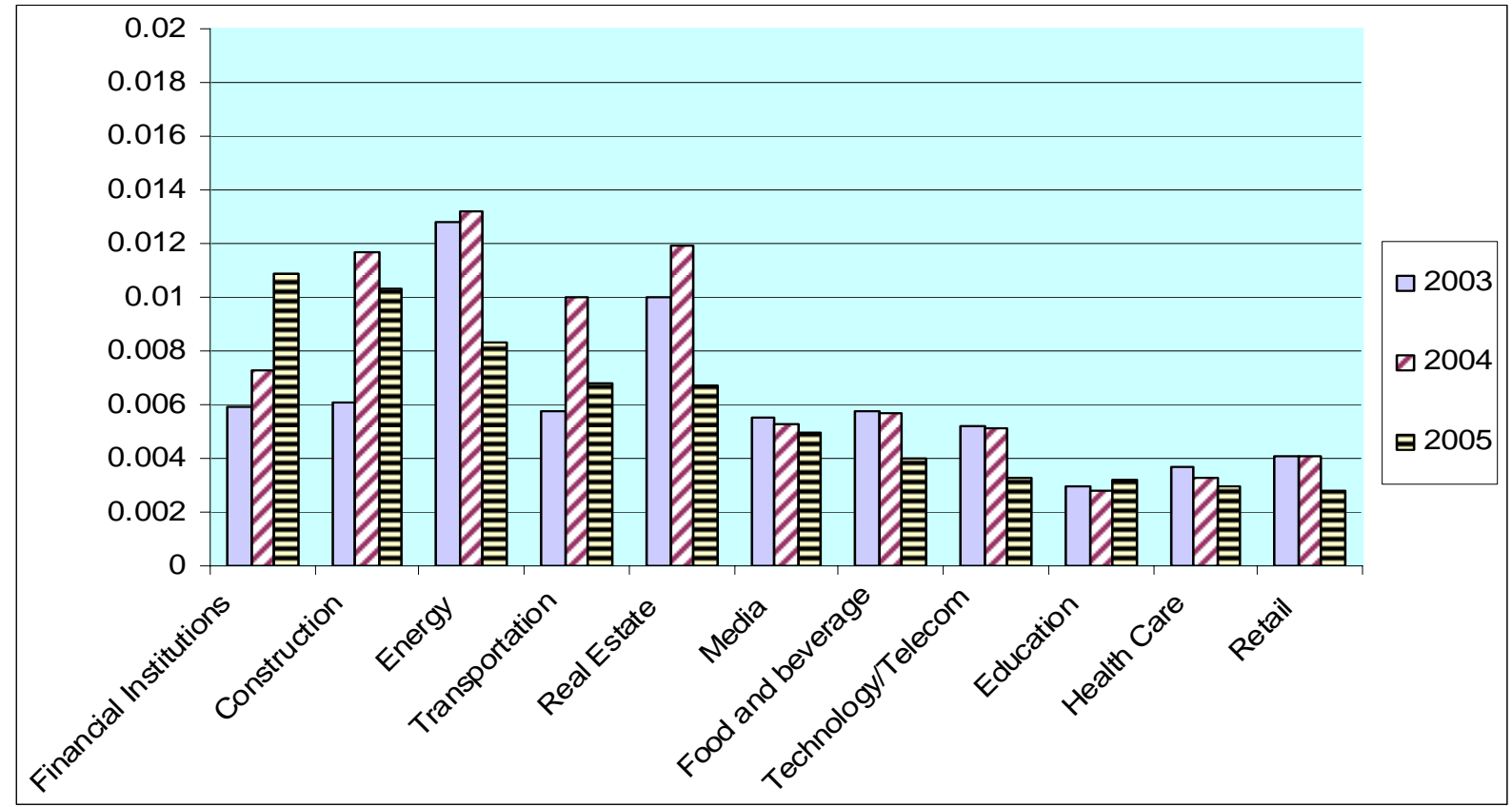

Sources: Authors' compilation from data provided by Marsh

Note also that, in 2003, the energy sector faced the most costly terrorism insurance coverage (twice the price paid by financial institutions at that time). Over the past three years, however, there has been a dramatic increase for financial institutions due to a combination of several factors, including the concentration of such institutions in large cities ${ }^{24}$ and their greater need to reassure their customers, derivatives counterparties, and deposit holders of their creditworthiness.

Moreover, data provided in Figure 1 include both TRIA and stand-alone coverage, the latter typically being more expensive. In the case of companies with large property value to be covered in major cities, which is often the case for financial institutions, the capacity provided by the market under TRIA is often insufficient. Thus the companies need to turn to the stand-alone market, sometimes for a large portion of the quantity of insurance coverage they need to purchase.

\footnotetext{
${ }^{24}$ Long considered as prime targets, cities are now viewed as even higher targets after some information about terrorists planning to attack Wall Street and other financial centers was made public in the recent years.
} 


\section{International Comparison: Why the Choice of the Measure of Price Matters}

We now provide a comparison of terrorism insurance pricing in these markets, starting with the question of the choice of the measure of price that, we believe, needs to be clarified.

\section{Price versus Price}

How does one define the price of terrorism insurance? As discussed above, most published works on terrorism risk insurance in the U.S. use the median of the distribution of all clients of the ratio of premium over total insured value (TIV) as their measure of price.

Nevertheless, what is considered the "right" measure of terrorism insurance price can differ in at least two ways: First, one shall consider not only the median of the distribution of clients but also the mean. Second, and perhaps even more important, another measure of price that ought to be considered is "premium over limit," which is the ratio of premium charged to the effective quantity of insurance purchased (i.e., "the limit"). ${ }^{25}$

What happens when we vary these definitions and types of coverage and compare them between the two countries is quite illustrative. Here we provide a detailed analysis of U.S. and German prices by focusing on the following two sets of data: (1) the sample of 1,623 Marsh clients at the end of 2005 for the U.S. market (excluding stand-alone for large companies with TIV higher than \$200 million); and (2) the 1,153 contracts covered by Extremus by the end of September 2006 for Germany $^{26}$ (which by definition also exclude stand-alone). ${ }^{27}$

We focus on the means of these distributions rather than the medians. We run the data for all companies (as summarized in Table 2-a) and for financial institutions only (Table 2-b); and we also differentiate by size of firm. Finally, we compare prices depending on whether the definition is "premium over TIV" or "premium over limit". The last column on the right reports the multiple of German prices in relation to those in the U.S.

As can be seen in the tables, five years after 9/11 there is a remarkable disparity between the U.S. and Germany in the price of coverage. After taking into

\footnotetext{
${ }^{25}$ Our discussion with Marsh and Extremus indicates that many companies, especially the larger ones, decide to purchase a limit that is much lower than their total insured value in order to decrease premiums paid. In order to fit with the two segments as defined by Extremus (below and above $€ 150$ million TIV, roughly $\$ 200$ million), it is interesting to split the Marsh data into these two categories. For accounts with TIV under $\$ 200$ million, the median of limit over TIV is $100 \%$ and the average is $83 \%$. For accounts with TIV over $\$ 200$ million, the median of limit over TIV is $36 \%$ and the average is $47 \%$. This does not come as a surprise: large accounts tend to have many locations; hence, they buy limit only up to a certain worst case scenario loss level. Accounts below $\$ 200$ million tend to have fewer locations and, in many instances have one very large location. We thank John Rand for pointing that out to us.

${ }^{26}$ We are grateful to Marsh's John Rand and Jill Dalton and Extremus' Bruno Gas for providing us with special runs of their datasets for the purpose of this study.

${ }^{27}$ We recognize these data do not represent the complete set of firms covered against terrorism, but they provide a good representation for middle- and large-size accounts.
} 
account differences in the size of the firms and in the definitions of insurance price, the price of comparable coverage in Germany appears to be at least 30\%-and, by some estimates, as much as four times-higher than in the U.S. On the other hand, if we confine our comparison to just financial institutions and consider the aggregate samples, the price of coverage appears roughly equivalent. For smaller firms, the price is up to two or three times lower in Germany than it is in the US, but 50\% to $80 \%$ higher for large accounts (depending on what measure of price one selects). This result can be explained in part by the fact, that Extremus does not charge different premiums to different industry sectors while, as we have already noted, premiums in the U.S. are highest for financial institutions.

Table 2-a. Terrorism Insurance Price Comparison between the U.S. and Germany

(mean, excluding stand-alone_overall book)

\begin{tabular}{|l|c|c|c|}
\hline Overall book & U.S. & Germany & $\begin{array}{c}\text { Difference } \\
\text { Germany/U.S. }\end{array}$ \\
\hline Aggregate & & & $\sim 1.9$ \\
\hline Premium/TIV & $0.0081 \%$ & $0.0154 \%$ & $\sim 2.5$ \\
\hline Premium/Limit & $0.0270 \%$ & $0.0685 \%$ & $\sim 1.8$ \\
\hline \hline Small accounts & $<\mathbf{\$ 2 0 0} \mathbf{~ m i l l i o n}$ & $<\mathbf{€ 1 5 0} \mathbf{~ m i l l i o n}$ & $\sim 1.3$ \\
\hline Premium/TIV & $0.0119 \%$ & $0.0216 \%$ & \\
\hline Premium/Limit & $0.0185 \%$ & $0.0240 \%$ & $\sim 2.4$ \\
\hline \hline Large accounts & $>\mathbf{\$ 2 0 0} \mathbf{~ m i l l i o n}$ & $>\mathbf{€ 1 5 0} \mathbf{m i l l i o n}$ & $\sim 4.1$ \\
\hline Premium/TIV & $0.0060 \%$ & $0.0143 \%$ & $0.1299 \%$ \\
\hline Premium/Limit & $0.0317 \%$ & & \\
\hline
\end{tabular}

Table 2-b. Terrorism Insurance Price Comparison between the U.S. and Germany (mean, excluding stand-alone-financial institutions only)

\begin{tabular}{|c|c|c|c|}
\hline Financial Institutions & U.S. & Germany & $\begin{array}{c}\text { Difference } \\
\text { Germany/U.S. }\end{array}$ \\
\hline \multicolumn{4}{|l|}{$\overline{\text { Aggregate }}$} \\
\hline Premium/TIV & $0.0255 \%$ & $0.0266 \%$ & $\sim 1.0$ \\
\hline Premium/Limit & $0.0697 \%$ & $0.0688 \%$ & $\sim 1.0$ \\
\hline Small accounts & $<\$ 200$ million & $<€ 150$ million & \\
\hline Premium/TIV & $0.0392 \%$ & $0.0214 \%$ & $\sim 0.5$ \\
\hline Premium/Limit & $0.0782 \%$ & $0.0259 \%$ & $\sim 0.3$ \\
\hline Large accounts & $>$ \$200 million & $>€ 150$ million & \\
\hline Premium/TIV & $0.0190 \%$ & $0.0288 \%$ & $\sim 1.5$ \\
\hline Premium/Limit & $0.0796 \%$ & $0.1400 \%$ & $\begin{array}{ll}\sim 8 \\
\end{array}$ \\
\hline
\end{tabular}

We believe this more granular analysis, with a special focus on what one means by the price of insurance, should be carefully considered when the future of these two programs after 2007 is decided.

As we discussed above, there is no systematic data collection on terrorism insurance market in the U.K. that we are aware of. For sake of comparison, however, it is fair to assume insurers there would certainly charge what they are charged by PoolRe for coverage (a price, as defined by premium over TIV, of $0.051 \%$, if total exposed property values for material damage and business interruption are the same 
and both covered, and which does not differ from one industry to another) plus a loading factor; this would result in a price that is several times higher in the U.K. than it is in the U.S. as well.

Both the significant price decrease in the U.S. and differences in premium level between the U.S. and Germany can be expected to have major effects on the demand for insurance in these two countries. We now turn our analysis to the evolution of our second metric, market penetration.

\section{TeRroRism InsURANCE MARKETS Five YeARS AFTER 9/11: MARKET PENETRATION (WHO'S BUYING TERRORISM INSURANCE, WHO'S NOT?)}

This section discusses evidence of the demand for terrorism coverage in the U.S. and compares it to the situation in Germany, where the very low take-up rate raises major concerns.

\section{Significant Increase in Market Penetration in the U.S.}

Thanks to the passage of TRIA, commercial coverage against terrorism in the U.S. has evolved in significant ways. Indeed, when the Council of Insurance Agents and Brokers $(\mathrm{CI} A \mathrm{~B})$ undertook the first national survey on the demand for terrorism coverage in 2002 (CIAB, 2003-a), 48\% of the member group handling the largest accounts (customers who pay more than $\$ 100,000$ annually in commission and fees to the broker) indicated that fewer than one in five of their customers had purchased terrorism insurance. The low demand was even more pronounced for smaller companies (less than $\$ 25,000$ in commission and fees to the broker), where almost two-thirds of the brokers indicated that less than 1 in 5 customers were purchasing insurance against terrorism. According to another national survey by the CIAB a few months later, $72 \%$ of the brokers indicated that their commercial customers were still not purchasing terrorism insurance coverage (CIAB, 2003-b).

Even in locations like New York City, the level of demand remained low in 2003. During the autumn of 2003, the New York-based insurance brokerage firm Kaye Insurance Associates surveyed 100 of its clients in the middle-market real estate, retail, and manufacturing in the New York area on a series of insurance-related issues, including terrorism insurance. Only $36 \%$ of the companies indicated that they had purchased terrorism insurance (Kaye, 2003) ${ }^{28}$

This proportion of insured firms increased dramatically in 2004 and 2005. As can be seen in Figure 2, the above cited Marsh survey shows a significant and fairly continuous increase of the take-up rate, from 23\% in the second quarter of 2003 to $64 \%$ in the fourth quarter of 2005 . But, as we saw earlier in the case of terrorism insurance pricing, there are important differences in take-up rates among different industry sectors.

\footnotetext{
${ }^{28}$ These recent figures are consistent with data published by Aon earlier in 2006; see Aon (2006-b).
} 
Figure 2. Evolution of Terrorism Insurance Take-up Rate in the U.S.

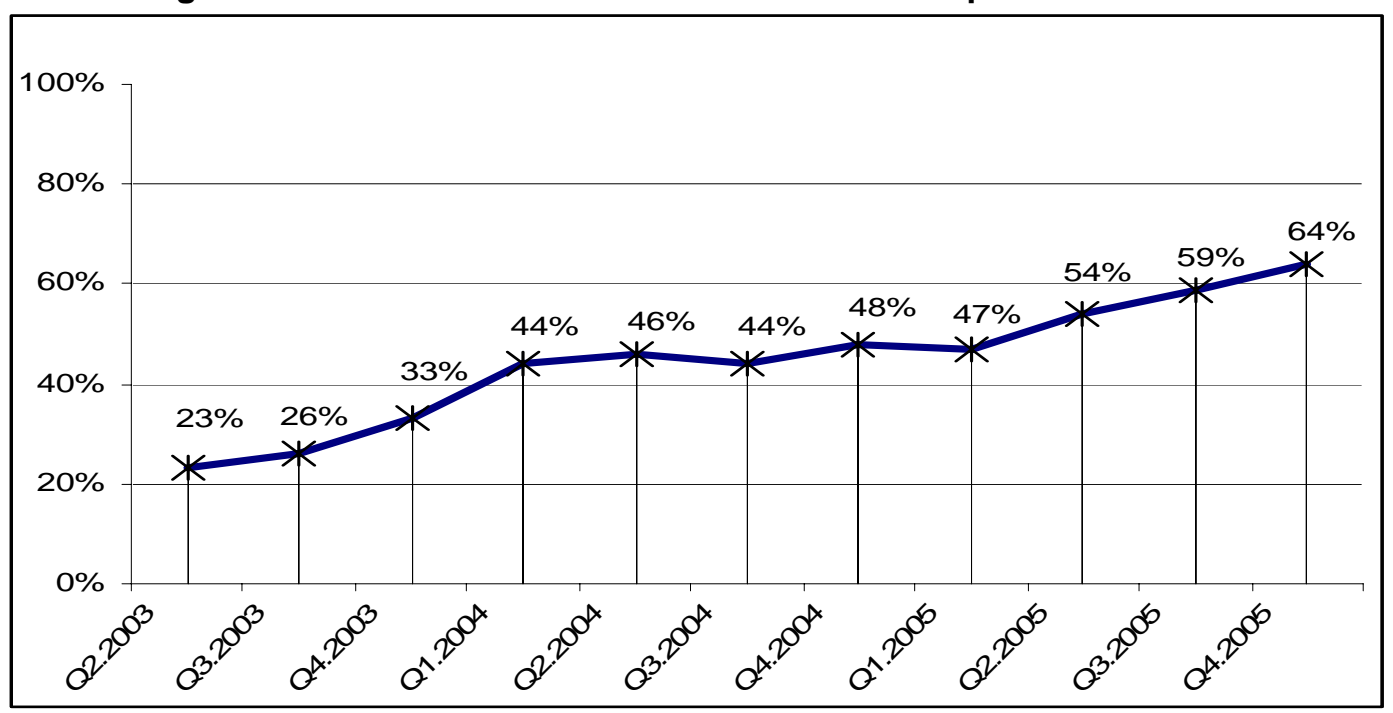

Between 2003 and 2005, as shown in Figure 3, take-up rates in most sectors jumped from a $10-30 \%$ to a $50-80 \%$ range (in other areas, notably energy, they have remained largely unchanged). In the past two years, financial institutions in particular, along with real estate, have had the highest take-up rates-nearly $80 \%$.

Figure 3. Evolution of terrorism insurance take-up rate by sector in the U.S. (2003-2005)

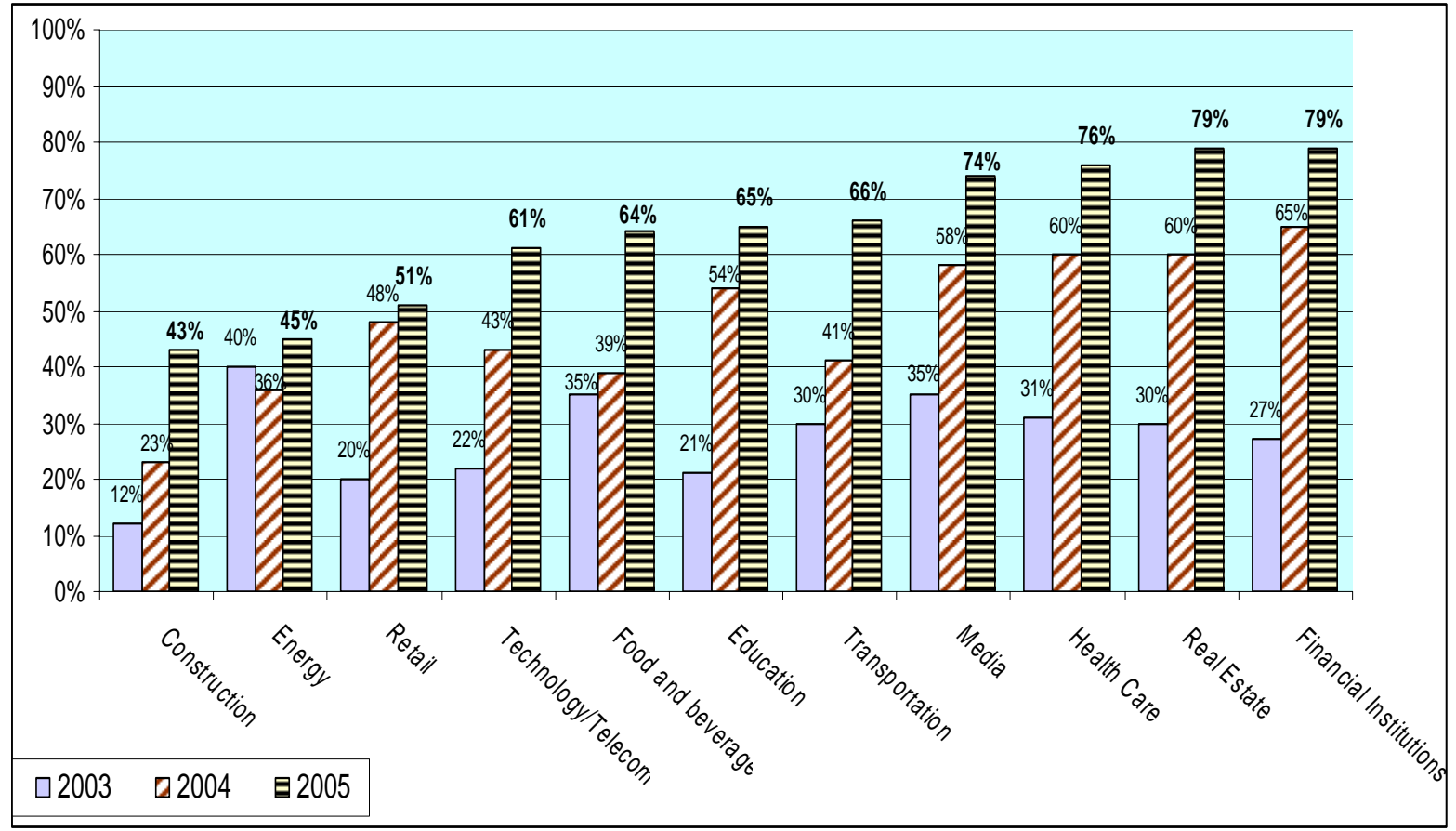

Sources: Authors' compilation from data provided by Marsh 
A major terrorist attack, which is more likely to occur in large cities, would actually have a double impact on financial institutions-on both their own properties and their loan portfolios. At the end of 2005 , the take-up rates of sectors like financial institutions, real estate, health care, and media were nearly twice the rates in other sectors like construction or energy.

Why Do More Companies Now Buy Terrorism Coverage in the U.S.?

There are several possible explanations for the increased portion of firms surveyed that now buy some type of insurance coverage against terrorism. We highlight five of them below.

Price decrease. One explanation for the increase in demand in 2004 and 2005 is the decline in the price of terrorism coverage to half of what it was during the first quarter of 2003, just after TRIA was implemented. In addition, the decreases in property insurance rates have enabled companies to free up funds from predetermined insurance budgets to purchase terrorism insurance coverage. These and other data discussed below suggest both price responsiveness and demand shifts.

New alerts and successful attacks. Another factor that may have led to increased purchase of terrorism insurance is the series of alerts released by the federal government in the last two years. For example, there have been several severe alerts of terrorist groups seeking to attack financial centers in New York and Asia. Moreover, successful attacks against countries allied to the United States (such as the Madrid bombing in 2004 and the bombings in London and Jordan in 2005) have made it clear that the threat of terrorism remains very real.

Requirement by banks. Another fundamental driver of terrorism coverage in specific industries, such as real estate, has been the requirements by lenders and some rating agencies for terrorism coverage, especially in high risk areas. Banks often require terrorism insurance coverage as a condition for loans and mortgages to protect their own financial interests. For example, a survey published in 2004 by the Mortgage Bankers Association (MBA) of 123,000 commercial/multifamily loans (totaling $\$ 656$ billion) showed that terrorism insurance was required by the mortgage investor and/or servicer on $\$ 616$ billion (over 90\%) of these loans (Congressional Budget Office, 2005).

Occurrence of other catastrophes. In the last few years, the U.S. has experienced extreme events from sources other than terrorism, including the major Northeast blackout in August 2003, the four hurricanes that devastated Florida in 2004, and Katrina in 2005 (which set a new record for hurricane-inflicted economic losses). These other events have certainly kept the question of financial protection against catastrophes at the top of the agenda of many decision-makers in the private sector.

D\&O Liability. In the current Sarbanes-Oxley environment, many executives are likely to prefer buying insurance rather than exposing themselves to the risk of being sued for negligence should their firm be the target of a terrorism attack. For this reason, terrorism insurance is often required as part of director's and officer's (D\&O) coverage, which itself has been a growth area for corporate insurance in the last three years. 


\section{Why Other Companies in the U.S. Still Do -Not- Buy Terrorism Insurance?}

Although the proportion of insured firms has increased in the past three years, many companies continue to operate without TRIA-insurance coverage. There might be a few reasons why they have made such a decision.

First, it is likely that a large proportion of companies do not see themselves as being a target ("it will not happen to us"), a reason cited by $90 \%$ of the responders to a U.S. Treasury survey of firms that did not purchase terrorism insurance (U.S. Department of Treasury, 2005).

Moreover, a company that does not buy terrorism insurance is effectively covered against terrorism for worker's compensation in all states but one and for fire following an attack (which is likely) in half the states.

Finally, current terrorism insurance policies typically do not cover against CBRN attacks, which are viewed by many as the main source of potential catastrophe. And even in the case of the risks covered by terrorism insurance, many companies may decide that it's more economical to self-insure against such risks by increasing the equity cushion provided by shareholders.

\section{Extremely Low Market Penetration for Firms Eligible for Extremus Coverage in Germany}

This last consideration is certainly an important driver of the very low degree of market penetration we observe today in Germany. According to Extremus, in June of 2006, only 13 of the 30 largest listed German companies (those that make up the DAX30) had purchased terrorism insurance. This number has remained essentially unchanged during the past three years. Among all companies eligible for coverage by Extremus, the market penetration is even smaller.

In September of 2006, only 1,153 contracts had been signed for terrorism insurance from Extremus, as compared to an estimated 40,000 eligible fire insurance contracts with a TIV of over €25 million (for an implied market penetration by Extremus of nearly 3\%). This number of companies, along with the $3 \%$ penetration rate, has remained essentially unchanged since the launch of Extremus in $2002 .^{29}$

If we consider the size of terrorism insurance contracts, we would get a somewhat higher market penetration; but we still do not see figures similar to those we observe in the U.S. market. Extremus has estimated that the TIV for commercial property for large risks above the $€ 25$ million threshold (that is, of its potential clients) amounts to $€ 3.5$ trillion. Using this estimate, the Extremus' TIV of $€ 409$ billion would yield a market penetration of $12 \%$.

\footnotetext{
${ }^{29}$ For the vast majority of contracts with sums insured below $€ 25$ million terrorism coverage is included in fire insurance yielding a coverage rate for these small risks of almost 100\%; however, it is problematic to talk about 'market penetration' in this case, because there is no separate market for these risks.
} 
But if the number of terrorism insurance contracts has stayed essentially the same between 2003 and 2006, there has been some significant restructuring of the portfolio of contracts during that time. The standard deductible that was set at $1 \%$ of total value insured for all clients at the outset in 2002 was no longer mandatory starting in 2005. As a result, insureds can now choose a smaller or a higher deductible. In particular, large clients tend to choose higher deductibles to reduce their cost of terrorism coverage.

The decline in premium income in the industrial, communication, and transport/tourism sectors that can be seen in Figure 4 is partly attributable to this effect. Another driver of this change was the loss of some of the largest accounts in these sectors. As mentioned above, these sectors also exhibit the lowest ratio of limit over TIV ( $4 \%$ for the industrial and communication sectors).

Insureds obviously expect that, in the event of a terrorist attack, only the smallest part of their property will be affected because their risk is diversified by many locations per firm (think, for instance, about the infrastructure of a nationwide telecommunications provider).

Figure 4: Evolution of premium income of Extremus by sector (in million euros)

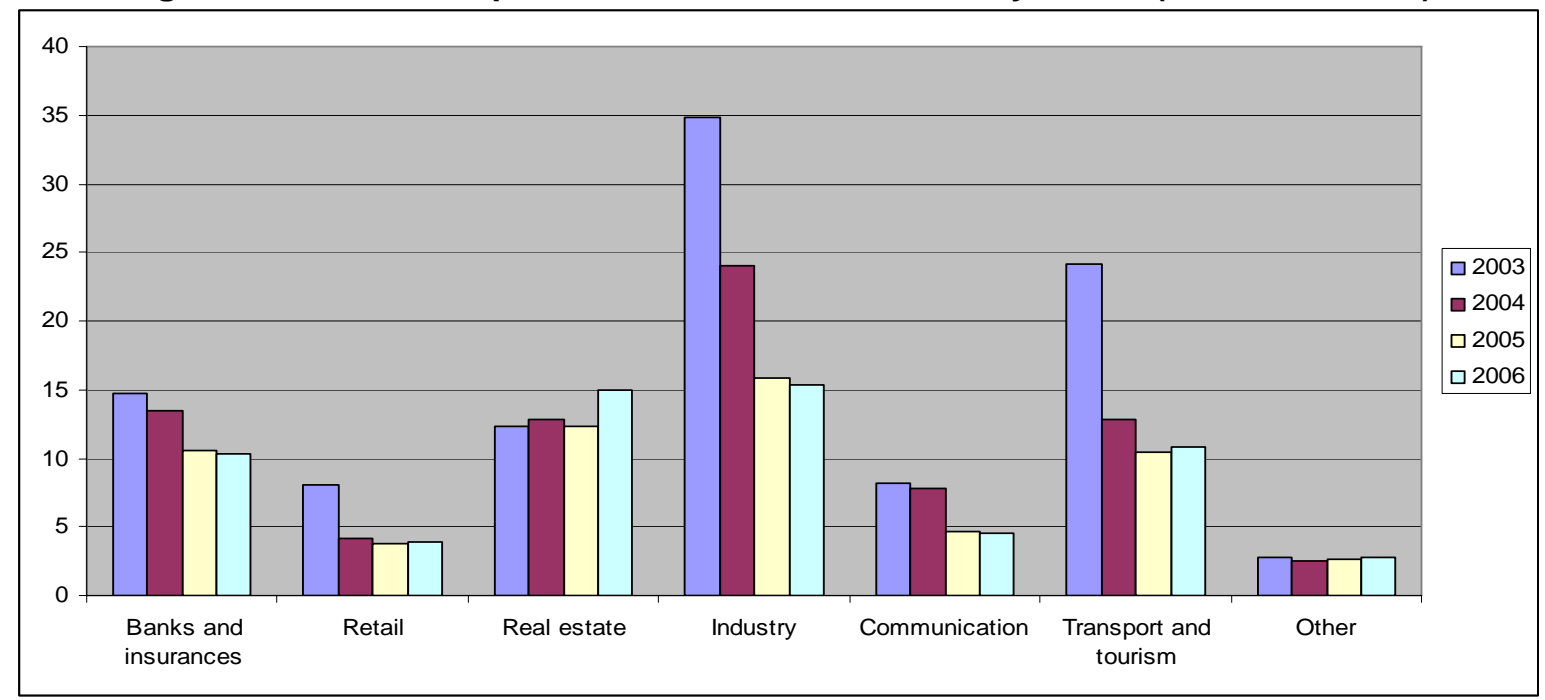

Sources: Authors' Compilation from Data provided by Extremus

At the other end of the spectrum are banks/insurance companies and real estate firms, with ratios of limit over TIV of $39 \%$ and $77 \%$, respectively. These higher ratios may well reflect a high degree of risk aversion stemming from financing arrangements and regulation, as well as to relatively heavy concentrations of real estate funds in a few locations. Nonetheless, premium income in the bank/insurance sector declined by almost $30 \%$ over the period under consideration, which is partly a consequence of a $20 \%$ decline in the number of accounts. ${ }^{30}$

\footnotetext{
${ }^{30}$ According to Extremus multiple contracts of the same pension funds account for as much as half of these not-renewed accounts. Even so, this decline is directly opposed to the general evolution of the take-up behavior of financial institutions in the U.S.
} 


\section{CONCLUSION}

This paper analyzes terrorism insurance markets in three economies where commercial enterprises are not required by law to buy such coverage: the United States, the United Kingdom, and Germany. Our analysis of the available data shows huge disparities among these countries in the kinds of terrorism coverage, the price of the insurance, and the current take-up rates.

These disparities may reflect differences among the nations' views of the threat of a mega-attack, as well as cultural differences. In the U.S. five years after 9/11, financial institutions have the highest take-up rate, as well as the highest cost of terrorism insurance, of all U.S. industries. This can be attributed to specific requirements, the perception of a higher threat for this sector as terrorist groups seek to inflict major economic disruption, and to the location of many of these companies in high-density areas where attacks can inflict mass casualties. The high take-up rate in this sector may well also reflect a greater concern, in the wake of Sarbanes-Oxley, about possible liability should executives be deemed to have failed to protect corporate assets.

In 2005, both the U.S. and Germany renewed their terrorism insurance programs for two more years. At present, however, it is unclear what will happen after 2007. Moreover, since CBRN attacks won't be covered for property and business interruption in either the U.S. or Germany, the question of who will pay for those economic losses from such attacks remains unaddressed ${ }^{31}$.

Deliberately, we do not discuss in this paper the rationale of government participation into a national program to cover against terrorism. But we believe that mega-terrorism presents a set of very specific characteristics that call for such participation, not merely a "government intervention" because of so-called market failures (the refusal of insurers to cover some risks does not constitute necessarily a market failure but rather a signal that some risks do not meet criteria of insurability) but because of government responsibility in providing security, its capacity to influence the risk and role in contributing to fast recovery ${ }^{32}$.

\footnotetext{
${ }^{31}$ France, which was the first country post 9/11 to establish a terrorism reinsurance program (Gareat), has passed a new law in 2006 which does not allow insurers to exclude any types of NBCR terrorist attacks from their policies (Journal Officiel, 2006). One possible interpretation of the law is that even a large-scale nuclear attack perpetrated against France using a stolen nuclear bomb (including the possibility of a nuclear missile launched from abroad) would be covered by Gareat. In that sense, this law makes of France the country that offers the largest NBCR coverage. Gareat has been renewed for three years in January 2007 . Today over 70 reinsurers provide this national backstop program with some layer of coverage. For a discussion of the French solution and comparison with other programs, see Partner Re (2004), Michel-Kerjan and Pedell (2005).

${ }^{32}$ Among recent contributions on the role of public and private sectors in addressing the question of terrorism risk coverage are Skyes and Gron (2002), Kunreuther and Michel-Kerjan (2004, 2005a/b, 2006), Smetters (2004), Brown, Cummins, Lewis and Wei (2004), Jaffee (2005), Jaffee and Russell (2005), Cummins (2006), Dixon and Reville (2006), Macdonald (2006), Nutter (2006), Wall Street Journal (2006); see also Hirshleifer (1953) in the context of insurance of nuclear attacks about 50 years ago.
} 
When TRIA was renewed at the end of December 2005, Congress charged the President's Working Group on Financial Markets (PWG) with issuing a report that would "analyze and report on terrorism risk coverage conditions and solutions." ${ }^{33}$ In what came as a surprise to us, the PWG report published on September 30, 2006 does not attempt in any way to identify what might be the key features of a long-term solution.

In the coming months, there will be national debates as to whether these temporary programs should be renewed again and, if so, whether their coverage should be changed. Building on our work during the past five years on national security and financial protection against mega-terrorism, we recommend that the new Congress and/or the White House study possible solutions in much more detail than has been done so far. The critical issue here is the proper role for government, given the nature and size of terrorism risk and the optimal sharing of responsibility between the public and private sectors.

In the spirit of our quoting the MI-5's Director General, and as the White House recently stated, "while we have substantially improved our air, land, sea, and border security, our Homeland is not immune from attack" (White House, 2006), a robust mechanism to protect a country against the economic consequences of terrorism should be viewed as a vital element of any policy to ensure national security and economic growth. This is a question of leadership. If it is not addressed, the next attack might be an even more tragic wake up call than 9/11.

${ }^{33}$ TRIEA (2005), section 8; italics added. 


\section{References}

Aon Crisis Management (2006-a), Standalone Terrorism Insurance Market Update," March.

Aon (2006-b), 2006 US Property Report: A Tale of Two Markets, New York, April 2006.

Brown, J.R., Cummins, J.D., Lewis, C.M., and R. Wei (2004), "An Empirical Analysis of the Economic Impact of Federal Terrorism Reinsurance," Journal of Monetary Economics 51, 861- 898;

Council of Insurance Agents and Brokers (2003-a), "Many Commercial Interests Are Not Buying Terrorism Insurance, New CIAB Survey Shows." News Release, March 24.

Council of Insurance Agents and Brokers (2003-b), "Commercial Market Index Survey." News Release, July 22.

Cummins, D. and C. Lewis (2003), "Catastrophic Events, Parameter Uncertainty and the Breakdown of Implicit Long-Term Contracting: The Case of Terrorism Insurance," Journal of Risk and Uncertainty, 26, 153-178.

Cummins, D. (2006), "Should the Government Provide Insurance for Catastrophes?", Federal Reserve Bank of St. Louis Review, July/August 2006, 88(4), 337-79.

Dixon, L. and R. Reville (2006), "National Security and Private-Sector Risk Management for Terrorism", Chapter 18 in Auerswald, Branscomb, LaPorte and Michel-Kerjan (eds). Seeds of Disaster, Roots of Response: How Private Action Can Reduce Public Vulnerability. New York: Cambridge University Press, October 2006.

Doherty N., Lamm-Tennant J. and L. Starks (2003), "Insuring September 11th: Market Recovery and Transparency," Journal of Risk and Uncertainty, 26 (2/3), 179-199.

Enders, W. and T. Sandler (2006), The Political Economy of Terrorism, Cambridge University Press.

Extremus Versicherungs-AG, Annual Report 2005, as well as Press Releases, April 12, 2005 and April 19, 2006, Cologne.

Hale, D. (2002), "America Uncovered," Financial Times, September 12.

Hirshleifer, J. (1953), "War Damage Insurance," The Review of Economics and Statistics, 35(2), 144-153.
Hoffman, B. (2006-a), Inside Terrorism, New York: Columbia University Press.

Hoffman, B. (2006-b), "Islam and the West: Searching for Common Ground", Testimony presented to the U.S. Senate Foreign Relations Committee, July 18, 2006.

Intelligence and Security Committee, The Rt. Hon. Paul Murphy (Chairman) (2006), Report into the London Terrorist Attacks on 7 July 2005. Presented to Parliament by the Prime Minister by Command of Her Majesty, May.

Jaffee, D. and T. Russell (2005), "Should governments Support the Private Terrorism Insurance Market?" paper presented at The World Risk and Insurance Economics Conference Salt Lake City August 2005.";

Jaffee, D. (2005), "The Role of Governments in the Coverage of Terrorism Risks," in Catastrophic Risks and Insurance, Policy Issues in Insurance, No. 8, OECD.

Jaffee, D. and T. Russell (2003), "Market Under Stress: The Case of Extreme Event Insurance" in Arnott, R., Greenwald, B., Kanbur, R. and Nalebuff, B. (eds), Economics for an Imperfect World: Essays in Honor of Joseph Stiglitz. Cambridge, MA: MIT Press.

Journal Officiel (2006), French Law $N^{\circ}$ 2006-64 relative to anti-terrorism. January 23, 2006, Paris: National Assembly and Senate.

Kaye Insurance Associates (2003), Middle Market Survey. October, New York. 44. Marsh (2006), Marketwatch: Terrorism Insurance 2006. These recent figures are consistent with data published by Aon earlier this year; see Aon, 2006 US Property Report: A Tale of Two Markets, New York, April 2006.

Kunreuther, $H$. and $E$. Michel-Kerjan (2006), "Looking Beyond TRIA: A Clinical Examination of Potential Terrorism LosS Sharing," U.S. National Bureau of Economic Research, Working Paper \#12066, Cambridge, MA; paper presented at the NBER Summer Institute of Economics of National Security, Boston: July.

Kunreuther, H. and E. Michel-Kerjan (2005a), "Insuring (Mega)-terrorism: Challenges and Perspectives," in Organization for Economic Cooperation and Development (2005). Terrorism Insurance in OECD Countries. Paris: OECD, July 5 . 
Kunreuther, H. and E. Michel-Kerjan (2005b), "Terrorism Insurance 2005: Where Do We Go from Here?," Regulation. The Cato Review for Business and Government, Washington, DC: The Cato Institute, Spring 2005 pp. 44-51.

Kunreuther, $H$. and $E$. Michel-Kerjan (2004), "Policy-Watch: Challenges for Terrorism Insurance in the United States," Journal of Economic Perspectives, 18(4), Fall 2004, 201-214.

Lagadec, P. and E. Michel-Kerjan (2005), "A New Era Calls for a New Model," International Herald Tribune (published by the New York Times), November 1.

Lakdawalla, D. and G. Zanjani (2005), "Insurance, Self Protection, and the Economics of Terrorism," Journal of Public Economics 89, 1891-1905.

Macdonald, J. (2006), "Terrorism, Insurance, and Preparedness: Connecting the Dots", Chapter 20 in Auerswald, Branscomb, LaPorte and Michel-Kerjan (eds). Seeds of Disaster, Roots of Response: How Private Action Can Reduce Public Vulnerability. New York: Cambridge University Press, October 2006.

Marsh (2006), Marketwatch: Terrorism Insurance 2006.

Meade, C. and R. Molander (2006), "Considering the Effects of a Catastrophic Terrorist Attack," Rand Corporation, Santa Monica, CA, August 2006.

Michel-Kerjan, E. and B. Pedell (2005), "Terrorism Coverage in the Post-9/11 Era: A Comparison of New Public-Private Partnerships in France, Germany and the U.S.", The Geneva Papers on Risk and Insurance, 30, 144-170.

Morgan Stanley (2004), "Assessing Insurer's Terrorism Risk," Equity Research, Insurance Property and Casualty, March.

Nutter, F. (2006), "Financing Catastrophe Risk with Public and Private (re)Insurance Resources, Chapter 21 in in Auerswald, Branscomb, LaPorte and Michel-Kerjan (eds). Seeds of Disaster, Roots of Response: How Private Action Can Reduce Public Vulnerability. New York: Cambridge University Press, October 2006.

OECD (2005), Terrorism Insurance in OECD countries, July 5, Paris: Organization for Economic Cooperation and Development.

Partner Re (2004), Terrorism Insurance. Pools. \& Market Solutions in Europe. May.
President's Working Group on Financial Markets (2006), "Terrorism Risk Insurance", September.

Rosoff, H. and D. von Winterfeldt (2006), "A Risk and Economic Analysis of Dirty Bomb Attacks on the Ports of Los Angeles and Long Beach," CREATE, University of Southern California, Los Angeles.

Sykes, A. and A. Gron (2002), "Terrorism and Insurance Markets: A Role for the Government as Insurer?" (July 2002). University of Chicago Law \& Economics, Olin Working Paper No. 155.

Smetters, K. (2004), "Insuring against Terrorism: The Policy Challenge," In Litan, R. and Herring, R. (eds), Brookings-Wharton Papers on Financial Services, 139-182.

U.S. Congress (2005), Terrorism Risk Insurance Extension Act of 2005. S.467. Washington, D.C., December 14.

U.S. Congress (2002), Terrorism Risk Insurance Act of 2002. H.R. 3210. Washington, D.C., November 26.

U.S. Department of Treasury (2005), Assessment: The Terrorism Risk Insurance Act of 2002, Washington, DC, June 30.

U.S. Department of State (2004), Global Patterns in Terrorism. Office of the Coordinator for Counterterrorism, Appendix G, June 22.

U.S. Government Accountability Office (GAO) (2006), "Terrorism Insurance: Measuring and Predicting Losses from Unconventional Weapons is Difficult, but Some Industry Exposure Exists," GAO-06-1081, Washington, DC, September 2006.

U.S. Government Accountability Office (GAO) (2005), Catastrophe Risk, U.S. and European Approaches to Insure Natural Catastrophe and Terrorism Risks, GAO-05199, Washington, D.C., February 28.

Wall Street Journal (2006), "Terrorizing Congress", Editorial, October 27, A14.

Wharton Risk Center- N. Doherty, E. Goldsmith, S. Harrington, P. Kleindorfer, H. Kunreuther, E. Michel-Kerjan, M. Pauly, I. Rosenthal and P. Schmeidler (2005), TRIA and Beyond. The Future of Terrorism Risk Financing in the U.S., The Wharton School, University of Pennsylvania, Philadelphia, pp. 230.

White House (2006), "9/11 Five Years Later: Successes and Challenges", Washington, D.C., September 2006. 
